\title{
Effects of COVID-19 Lockdown on Health - Two Sides of the Coin
}

\author{
Khursheed Muzammil' ${ }^{1}$, Nazim Nasir ${ }^{2}$, Syed Esam Mahmood ${ }^{3}$, Atiq Ul Hasan ${ }^{4}$, \\ Abdullah A Alsabaani ${ }^{5}$, Irfan Ahmad 6 , Pradeep Aggarwal7 , Izhar Hussain ${ }^{8}$, Zeba Siddiqui ${ }^{9}$
}

\begin{abstract}
${ }^{1}$ Department of Public Health, College of Applied Medical Sciences, Khamis Mushayt Campus, King Khalid University, Abha, Kingdom of Saudi Arabia (KSA). 2, 4 Department of Basic Sciences, College of Applied Medical Sciences, Khamis Mushayt Campus, King Khalid University, Abha, Kingdom of Saudi Arabia (KSA). 3, 5 Department of Family \& Community Medicine, College of Medicine King Khalid University, Abha Kingdom of Saudi Arabia (KSA). 6 Department of Clinical Laboratory Science, College of Applied Medical Sciences, King Khalid University, Abha, Kingdom of Saudi

Arabia (KSA). ${ }^{7}$ Department of Community and Family Medicine, All India Institute of Medical Sciences (AIIMS),

Rishikesh, Uttarakhand, India. ${ }^{8}$ Department of Management, Seacom Skills University, Kolkata, West Bengal, India.

${ }^{9}$ Department of Dental Surgery, Muzaffarnagar Medical College, Muzaffarnagar, CCS University, Uttar Pradesh, India.
\end{abstract}

\section{ABSTRACT}

Coronavirus disease (COVID-19) is an acute respiratory illness caused by a highly contagious novel coronavirus creating catastrophe globally. With no specific treatment and approved vaccine for COVID-19 till date, the practice of social distancing, preferably called physical distancing and staying home has been adopted as a part of the prevention and control strategy against the spread of 2019-nCoV infection-causing COVID-19. But the implementation, extension and repetition of the lockdowns creates various threats not only on the economy but also on the psychosocial and behavioural changes in general. This article critically discusses the positive effects of lockdown along with its adverse possible outcomes or effects. The adverse effects experienced are multidimensional like psychosocial, mental and economical. The recent insurgence of COVID-19 cases, shortage of intensive care ventilators, quarantine, and ill effects of lockdown have led to depression, anxiety, insomnia, fear and insecurity in the common man. Worst ever economic recession has been noticed after COVID-19 lockdown. Consumer spending and buying power have also reduced significantly in all sectors. The looming crisis in developing nations is predicted to devastate economies disproportionately and ramp up inequality in such nations. This lockdown has pushed millions of people in various countries to no work, no income and hunger. The positive effects like reduction in air pollution, better lifestyle are also observed. The reduction in soil, water and air pollution is eventually helpful to live a healthy life. People are following proper hand washing practices, practicing respiratory etiquettes and maintaining proper personal hygiene and have embraced health promotion and disease prevention measures seriously. Traffic volume and street crimes have also been reported going down. Education has become digitalized and affordable. Family members are spending time with each other and developing gratitude towards their loved ones.

Food waste control is critical. This lockdown has improved the food shopping performances in some places and a positive behavioural change for the prevention of food wastage is expected in other countries also. Lockdown reduces the reproduction of coronavirus, i.e., to reduce people having confirmed infection and treated as a case. The goal is to keep the reproduction number ' $R$ ' below one $(R<1)$, through mitigation \& suppression. Embracing health promotion measures and practicing social responsibility is the need of the hour. However, policymakers should strive for maintaining a balance in measures in order to reduce the devastation of economies apart from safeguarding the health of the people.

\section{KEY WORDS}

COVID-19, Lockdown, Pandemic, Effects
Corresponding Author:

Dr. Syed Esam Mahmood

Professor, Department of Family and Community Medicine

College of Medicine, King Khalid University, Abha, Kingdom of Saudi Arabia (KSA)

E-mail:semahmood@gmail.com

DOI: $10.14260 /$ jemds/2020/873

How to Cite This Article:

Muzammil K, Nasir N, Mahmood SE, et al. Effects of COVID-19 lockdown on health: two sides of the coin. J Evolution Med Dent Sci 2020;9(52):3998-4002, DOI: $10.14260 /$ jemds/2020/873

Submission 30-08-2020,

Peer Review 03-11-2020,

Acceptance 09-11-2020,

Published 28-12-2020.

Copyright (C) 2020 Khursheed Muzammil et al. This is an open access article distributed under Creative Commons Attribution License [Attribution 4.0 International (CC BY 4.0)] 


\section{BACKGROUND}

The severe acute respiratory syndrome-related coronavirus2 , also referred to as $2019-\mathrm{nCoV}$ is a positive single-stranded RNA virus which belongs to the Coronaviridae family of Orthornavirae kingdom of viruses. It is causing nightmares to scientists and public health experts all over the world because of its contagious and deadly nature. That is why WHO (World Health Organization) has declared COVID-19 pandemic as a public health emergency of international concern. This virus colloquially called coronavirus is responsible for bringing the day-to-day life of many countries to halt through the recently imposed lockdown and other restrictions. This SARS-Co-2 is a strain of Severe Acute Respiratory Syndrome-Related Coronavirus (SARSr-CoV) and is said to be having a zoonotic origin. The novel coronavirus is genetically similar with that to bat coronavirus and is suspected to have emerged from a batborn virus.1-14 For the first time this novel corona virus was identified in the city of Wuhan, China. As per WHO, further spread internationally to 216 countries with 795132 deaths and this figure is still increasing.

\section{ADVERSE EFFECTS OF COVID-19 LOCKDOWNS}

There has been tremendous effect on human life all over due to the practice of social distancing, preferably called physical distancing and staying home. It is the primary intervention along with personal protection as part of the fight against the spread of 2019-nCoV infection-causing COVID-19. Due to the lack of specific treatment and vaccine for COVID-19 as of today, it is creating a triple effect along with lockdown, especially on the psychosocial aspects of people in general. A complete lockdown means people should remain or stay home with total movement control. No doubt, the preventive lockdowns are considered as pre-emptive lockdowns to mitigate the risk of transmission of infection that may be because of nonconformances to the normal situation. ${ }^{15}$ But the extension of the lockdown for further periods creates various threats not only on the economy but also on the psychosocial and behavioural changes in general. The critical effects of lockdown imposed in response to COVID-19 are discussed here.

\section{PSYCHOSOCIAL EFFECTS AND MENTAL HEALTH IMPACT OF LOCKDOWN}

Around 2.6 billion people globally were estimated to be in some sort of lockdown because of COVID-19. As of today, it is the biggest lockdown currently enforced in India, where 1.3 billion people are facing lockdown. In the USA, France, Spain, UK, Italy, and elsewhere, about 300 million people were under some form of lockdown. Ranging from partial to full lockdown, including more draconian laws in the Philippines where if someone found violating quarantine would be shot dead and in Jordan violation may result in imprisonment of one year. Altogether, these restrictions and movement limitations during lockdown are exerting a tremendous psychosocial effect on the common man. ${ }^{16}$ Social distancing is reigniting a sense of being trapped, resulting in mood swings among some people.

Ongoing lockdowns for extended periods with uncertain durations are worsening the mental health status of such individuals. The Indian Government has advised its citizens not to follow sensational news items, social media posts and other misinformation about COVID-19 illness. It is impacting the mental state of people at large during the lockdown. Most of the articles in the print media and discussions on the news channel / mass media focus on COVID-19 deaths. Instead, one should think about the good number of people being recovered from COVID-19. People may experience emotional issues and stress even after recovery from COVID-19, especially over fears of loved ones falling ill. The feeling of guilt for not able to work or care for others may cause depression, helplessness, or frustration. ${ }^{17}$ A veteran scientist of New Zealand Sir Peter Gluckman quoted that about one tenth of people with uncertainty and frustration might lead to depression and suicides. ${ }^{18}$ Such lockdowns are associated with psychosocial effects because of disease specific fear and anxiety, social isolation, depression, PTSD (Post-Traumatic Stress Disorders), high-stress levels, irritability, insomnia, and acute stress. ${ }^{19-27} \mathrm{~A}$ study conducted in Italy during lockdown among adults, reported that the primary mental health problems encountered among the respondents were depression, anxiety, insomnia, and adjustment disorder. ${ }^{28} \mathrm{~A}$ Chinese study reported $30 \%$ anxiety and $70 \%$ depression among the subjects during COVID-19 lockdown period. In another Chinese survey, nearly one third of the respondents were observed with trauma-related distress symptoms, with a higher proportion of women and young adults having psychological distress. The recent insurgence of cases, shortage of intensive care ventilators, quarantine, and ill effects of lockdown have to lead to depression, anxiety, insomnia, fear and insecurity in the common man.

\section{ECONOMY DEVASTATION DUE TO LOCKDOWN}

Worst ever economic recession has been noticed after COVID19 lockdown. UNDP (United Nations Development Program) on $20^{\text {th }}$ March 2020 stated that there is a looming crisis in developing nations that may devastate economies disproportionately and ramp up inequality in such developing nations. UNDP is seeking unprecedented COVID-19 support for vulnerable countries as there is not only a health crisis because of COVID-19 in the short term but also as a devastating socioeconomic crisis in the months and even years ahead. Loss of income crossed the US $\$ 220$ billion in developing nations. About $55 \%$ of the worlds' population is inaccessible to social protection, and these losses will rumble societies, affecting the education sector, human rights, and in extreme circumstances, underlying food security and nutrition also. Italy being already on the verge of economic recession, the government's steps cost hugely for the eurozone's third largest economy, which also has the bloc's second biggest debt pile next to Greece. The Italian stock exchange, which has decreased to around $17 \%$ since the epidemic in North Italy, it has come down further to $11 \%$ on $30^{\text {th }}$ March 2020 underperforming its regional peers because of massive lockdown all over the country. The government has promised the US $\$ 8.57$ billion to assuage the economic crisis. The IMF 
(International Monetary Fund) has recently announced that the 'Great Lockdown' recession tends to drag the global GDP lower by $3 \%$ in 2020. COVID-19 lockdowns have brought global economic activity to a halt. Many businesses are bound to shut down their operations, resulting in loss of a job, especially the service industry contributing significantly to many economies were among the hardest to hit during the COVID-19 lockdown. Due to lockdown, the overall unemployment rate globally has come down drastically, and in India, it has gone to $23.4 \%$. The USA is the world's largest economy; there also > 26 million jobs lost since the global emergency has been declared, and so the resulting lockdown. The unemployment rate in Australia and South Korea have also gets increased during the COVID-19 lockdown, and there is a possibility to be more worsened as speculated by economists. In retail sales, the USA \& China have reported a sharp decline due to lockdown measures. It is evident by now that almost the same situation every nation is facing as far as economic devastation gave COVID-19 is concerned. The lockdown procedures in India and Indonesia are said to be highly disastrous for the welfare of the people and their economies as small businesses are helpless from the government side. Further, there is no provision of unemployment benefits for the citizens. In India, about $65 \%$ of the population is youngsters, and such an extended lockdown in multiple of phases is responsible for more human sufferings as compared to COVID-19 itself. These extended phases of lockdown in India will, unfortunately, tend to suffer India with what we call in the language of economics as 'Consumer Lending Cycle,' which will worsen the economy further. Great lockdown will cost INR 7.5 lakh crore (US \$98 billion) during the first phase of lockdown to the Indian economy as a result of $70 \%$ cessation of economic activity in India. The COVID-19 great lockdown cost the Indian economy per day, nearly US $\$ 4.64$ billion (INR $>35,000$ crores). World Bank has reported that the Indian economy is estimated to have a growth rate of $1.5 \%$ to $2.8 \%$ during $2020-2021$ fiscal starting from $1^{\text {st }}$ Aril and tends to be the slowest growth rate recorded since the Indian economic reforms began in 1991. According to WTTC (World Travel \& Tourism Council), straightaway 50 million jobs are at risk in the tourism and travel sector, with almost 30 million of those jobs are of Asian employees. This sector accounts for $10.4 \%$ of global GDP; such a low pace economic recovery will have a severely detrimental effect on global economies. Consumer spending and buying power have also reduced significantly in all sectors. A significant portion of consumers are not interested in spending more money. Their income shortly is not going to stabilize. The consumer is a significant factor for the growth of the economy, and in its absence, economic growth is merely a dream.

\section{FOOD SCARCITY DURING A LOCKDOWN}

In India, many labourers are struggling for food to keep their hunger at bay. In Columbia, poor people are hanging redcoloured items of clothing and flags from their windows during lockdown to make others understand that they are under the immense need for food. COVID-19 lockdown has brought hunger to millions of peoples in various countries. During the lockdown, there is no work, so no income, and this lockdown is also disrupting agricultural production in the field, leaving millions of people to think of how to have enough food to survive. According to WFP (World Food Program), already 135 million people had been facing acute shortage of food, and COVID-19 lockdown has raised this figure to 265 million hungry people in 2020 . These 265 million people will be starving at the end of 2020 . It seems that instead of COVID19 , people will die of hunger. Recently WFP (UN) has warned that 'World is at high risk of the widespread famine of biblical proportions' because of COVID-19 catastrophe globally. People in about ten countries having the same sort of conflict, economic crisis, and climate change issues are more at risk of starvation. These countries are: Yemen, the Democratic Republic of the Cargo, Afghanistan, Venezuela, Ethiopia, South Sudan, Sudan, Syria, Nigeria, and Haiti. The world has to 'act wisely and act fast,' but unfortunately, we lack weapons to prevent it. However, COVID-19 containment is possible, and the second wave is in our hands. The global economy is not going to stabilize in the coming days because of the significant economic impact of COVID-19 great lockdown.

\section{POSITIVE EFFECTS OF COVID-19 LOCKDOWNS - AN EFFORT TO KEEP REPRODUCTION NUMBER $<1$}

Epidemiological studies suggest that each new corona infection results in 1.4 to 3.9 new cases when no community member is immune, and no preventive measures are taken. Prevention of COVID-19, lockdown is the only objective measure to maintain social distancing as there is no specific treatment \& vaccine to date. However, the vaccine is still in the developmental phase and will take some time to launch commercially. There is a curiosity in general as to how exactly this lockdown keeps all of us away from COVID-19? The easy way to understand this phenomenon is first to know the purpose of lockdown. Lockdown reduces the reproduction of coronavirus, i.e., to reduce people having confirmed infection and treated as a case definition. Our goal is to keep a copy, or reproduction number ' $R$ ' below one $(R<1)$, i.e., with each case infecting on an average fewer than one other person this goal, achieved through mitigation \& suppression. Without any lockdown of social distancing measures, one can see peak mortality in nearly three months. So, to get $\mathrm{R}<1$, lockdown is recommended, and no doubt for the existence of human beings' lockdown is the need of hour all over the world, and there is no other substitute to it.

\section{BEHAVIOURAL CHANGE TO AVOID FOOD WASTE}

Food waste is a growing issue globally exerting a challenge to food security, food safety, economic and environmental sustainability. Food waste control is critical, especially in poor underdeveloped countries. A study conducted in Tunisia revealed that COVID-19 lockdown interestingly improved the food shopping performances and generate positive behavioural changes as far as the prevention of food wastage is concerned. This change is supposed to be driven by the socioeconomic context of COVID-19 lockdown. Similar 
behavioural change is expected to occur in other countries also. Still, during the great lockdown, there is a scarcity of such studies to support this viewpoint, which is in line with the United Nations agency WFP.

\section{REDUCTION IN AIR POLLUTION}

Data from NASA's Global Modeling and Data Assimilating Team has depicted a dramatic change in the levels of air pollution due to strict lockdown measures. The lockdown because of the COVID-19 pandemic has led to a significant increase in air quality all over the world. Lockdowns have forced the factories and transport closure, which in turn leads to a reduction in emission of gases and hence, reduction in air pollution levels in different parts of the world. It is evident that when factories are closed over an extended period, then definitely the soil and water pollution must also be reduced to a significant level like that of air pollution, however, no such study during the lockdown has been reported so far. So, the substantial effect in COVID-19 great lockdown on the reduction of air pollution all over the world is eventually helpful to breathe suitably and lead a healthy life.

\section{BETTER LIFE-STYLE AND SOCIAL CHANGES}

People are taking advices and learning proper hand washing practices, practising respiratory etiquettes and maintaining proper personal hygiene and have embraced health promotion and disease prevention measures seriously. Traffic volume and street crimes have also reported to be going down. Education has become digitalized and affordable too. Family members are spending time with each other, building genuine relationships and developing gratitude towards their loved ones.

\section{CONCLUSIONS}

We should remember that a functional mental status during this challenging time is the key to win the battle quickly. Altogether it can be emphasized that without further delay, there is a need for appropriate and proper assessment of the magnitude of mental health status and psychosocial problems that the common man has suffered during the lockdown. The global health emergency of COVID-19 may be regarded as having the potential to cause a severe impact on mental health and public health at large. It has tremendous psychosocial effects on various facets of life as a result of great lockdown. Monitoring mental health is vital during the pandemic as its effects may impede the control of infection, and strict lockdown laws may lead to unprecedented stressful conditions, ultimately leading to high long-term health costs. There are various promotive and preventive measures, (Table 1) recognized to keep depression and anxiety away from people during lockdown viz - (1) Avoid reading, watching or listening too much news coverage of COVID-19 (2) Try to maintain a routine or a disciplined life (3) Maintain social contacts with family \& friends using technology \& keeping social distancing at its place (4) Speak out to your close friends, (5) Create a new ritual to keep yourself busy. (6) Do mild to moderate home exercises, eat healthy foods and avoid tobacco, alcohol and drugs. (7) Practising spiritual behaviours like learning core values, spiritual reading, offering prayers, supporting social causes, showing unconditional love and being compassionate can-do wonders in such a situation. COVID-19 pandemic has been creating havoc in many countries as the curve is flattening rather condition is worsening. Somebody has rightly said 'Anything human is mentionable, and anything mentionable can be more manageable.' We must weigh the positive effects of lockdown with that of its adverse possible outcomes or consequences. Policymakers should try to have a more balancing measure to reduce the devastation of economies too, apart from safeguarding the health of the people.

\begin{tabular}{|cc|}
\hline Social Responsibilities & Health Promotions \\
Stay home & Spend time with family \\
Social distancing & Talk to close ones \\
Respiratory etiquettes & Do a hobby \\
Hand hygiene & Practice Spirituality \\
Face masks & Avoid COVID-19 news \\
Self - monitoring & Avoid misinformation \\
Seek medical advice & Proper diet, sleep \& exercise \\
Follow guidelines & Avoid tobacco, alcohol \& drugs \\
Cooperate policymakers & Relax, manage stress, \& meditate \\
\hline Table 1. COVID-19 Social Responsibilities and Health Promotions \\
\hline
\end{tabular}

Financial or other competing interests: None.

Disclosure forms provided by the authors are available with the full text of this article at jemds.com.

Authors are thankful to King Khalid University, Abha, Kingdom of Saudi Arabia for providing all the technical support \& help in completing this research work.

\section{REFERENCES}

[1] Robson MC, Steed DL, Franz MG. Wound healing: biologic features and approaches to maximize healing trajectories. Curr Probl Surg 2001;38(2):72-140.

[2] Messadi DV, Bertolami CN. General principles of healing pertinent to the periodontal problem. Dent Clin North Am 1991;35(3):443-57.

[3] Hupp JR. Wound repair. In: Peterson LJ, Ellis E, Hupp JR, et al, eds. Contemporary oral and maxillofacial surgery. $4^{\text {th }}$ edn. St. Louis: Mosby 2003:184-213.

[4] Polimeni G, Xiropaidis AV, Wikesjo UM. Biology and principles of periodontal wound healing / regeneration. Periodontol 2000 2006;41(1):30-47.

[5] Reddy S. Rationale for periodontal treatment. In: Reddy S, ed. Essentials of clinical periodontology and periodontics. $3^{\text {rd }}$ edn. New Delhi: Jaypee Brothers Medical Publishers (P) Ltd 2011: p. 269.

[6] Guo SA, Dipietro LA. Factors affecting wound healing. J Dent Res 2010;89(3):219-29.

[7] Wikesjo UM, Nilveus RE, Selvig KA. Significance of early healing events on periodontal repair: a review. J Periodontol 1992;63(3):158-65.

[8] Sporn MB, Roberts AB, Shull JH, et al. Polypeptide transforming growth factors isolated from bovine sources and used for wound healing in vivo. Science 1983;219(4590):1329-31. 
[9] Giri RR, Giri KR, Patel SS, et al. Effect of terminalia arjuna in accelerating healing process of experimentally fractured tibia of rats: a preliminary study. Research Journal of Pharmaceutical, Biological and Chemical Sciences 2012:3(4):417-25.

[10] Bathla S. General principles of periodontal surgery. In: Bathla S, ed. Periodontics revisited. $1^{\text {st }}$ edn. New Delhi: Jaypee Brothers Medical Publishers (P) Ltd; 2011: p. 340.

[11] Carranza FA, Takei HH. Gingival curettage. In: Newman MG, Takei HH, Carranza FA, eds. Carranza's clinical periodontology. $9^{\text {th }}$ edn. W.B Saunders Company 2002.

[12] Novaes AB, Kon S, Ruben MP, et al. Visualization of the microvascularization of the healing periodontal wound. III Gengivectomy. J Periodontol 1969;40(6):359-71.

[13] Kon S, Novaes AB, Ruben MP, et al. Visualization of the microvascularization of the healing periodontal wound. IV. Mucogingival surgery: full thickness flap. J Periodontol 1969;40(80):441-56.

[14] Clerehugh V, Tugnait A, Genco RJ. Types of periodontal surgery. In: Clerehugh V, Tugnait A, eds. Periodontology at a Glance. $1^{\text {st }}$ edn. Oxford. UK: A John Wiley \& Sons Ltd 2009. p. 51.

[15] Gargiulo AW, Arrocha R. Histo-clinical evaluation of free gingival grafts. Periodontics 1967;5(6):285-91.

[16] Gupta VK, Pathak SS. Screening of burn wound healing property of ocimum sanctum by grading of epithelial regeneration in rabbits. Research Journal of Pharmaceutical, Biological and Chemical Sciences 2016;7(3):538-42.

[17] Del Pizzo M, Modica F, Bethaz N, et al. The connective tissue graft: a comparative clinical evaluation of wound healing at the palatal donor site. A preliminary study. J Clin Periodontol 2002;29(9):848-54.

[18] Gordon HP, Sullivan HC, Atkins JH. Free autogenous gingival grafts. II. Supplemental findings--histology of the graft site. Periodontics 1968;6(3):130.

[19] Melcher AH. On the repair potential of periodontal tissues. J Periodontol 1976;47(5):256-60.
[20] Lafzi A, Farahani RM, Tubbs RS, et al. Enamel matrix derivative Emdogain $\AA$ as an adjuvant for a laterallypositioned flap in the treatment of gingival recession: an electron microscopic appraisal. Folia Morphol (Warsz) 2007;66(2):100-3.

[21] Amler MH, Johnson PL, Salman I. Histological and histochemical investigation of human alveolar socket healing in undisturbed extraction wounds. J Am Dent Assoc 1960;61(1):32-44.

[22] Nyman S, Rosling B, Lindhe J. Effect of professional tooth cleaning on healing after periodontal surgery. J Clin Periodontol 1975;2(2):80-6.

[23] Schilling T, Müller $M$, Minne $H W$, et al. Influence of inflammation-mediated osteopenia on the regional acceleratory phenomenon and the systemic acceleratory phenomenon during healing of a bone defect in the rat. Calcif Tissue Int 1998;63(2):160-6.

[24] Sculean A, Gruber R, Bosshardt DD. Soft tissue wound healing around teeth and dental implants. J Clin Periodontol 2014;41(Suppl 15):S6-22.

[25] Vignoletti F, Johansson C, Albrektsson T, et al. Early healing of implants placed into fresh extraction sockets: an experimental study in the beagle dog. De novo bone formation. J Clin Periodontol 2009;36(3):265-77.

[26] Rimondini L, Bruschi GB, Scipioni A, et al. Tissue healing in implants immediately placed into postextraction sockets: a pilot study in a mini-pig model. Oral Surg Oral Med Oral Pathol Oral Radiol Endod 2005;100(3):e43-50.

[27] Vignoletti F, De Sanctis M, Berglundh T, et al. Early healing of implants placed into fresh extraction sockets: an experimental study in the beagle dog. III: soft tissue findings. J Clin Periodontol 2009;36(12):1059-66.

[28] Araújo MG, Sukekava F, Wennström JL, et al. Ridge alterations following implant placement in fresh extraction sockets: an experimental study in the dog. J Clin Periodontol 2005;32(6):645-52. 